\title{
Phosphatides content in soybean oil as function of bean moisture content-at-harvest and storage-time
}

\author{
By Enzo A. Tosi, Ampelio F. Cazzoli, Edmundo D. Ré and Luis M. Tapiz \\ Centro de Investigación y Desarrollo en Tecnología de Alimentos \\ Universidad Tecnológica Nacional, Facultad Regional Rosario \\ Zeballos 1341, S2000 BQA Rosario, ARGENTINA \\ Telfax:54-41-484909, E-mail: tosienzo@ciudad.com.ar
}

\section{RESUMEN}

Contenido de fosfátidos en el aceite de soja en función del contenido de humedad en la cosecha y el tiempo de almacenamiento del poroto.

Se evaluó la influencia del contenido de humedad en la cosecha y el tiempo de almacenamiento del poroto de soja sobre el contenido de los fosfátidos totales y no hidratables en el aceite y la actividad de la fosfolipasa $\mathrm{D}$ en el poroto. Los porotos fueron cosechados con humedades entre el 14.4 y $33.3 \%$, secados con aire a $25^{\circ} \mathrm{C}$ hasta $12.8-13.5 \%$ y almacenados durante 245 días. Periódicamente se determinó el contenido de fosfátidos y la actividad de la fosfolipasa D. Para los valores más altos de humedad, el contenido inicial de fosfátidos totales fue alto, disminuyendo con el tiempo. En los porotos con humedades más bajas el contenido de fosfátidos totales se mantuvo en sus valores iniciales. El contenido de fosfátidos no hidratables está relacionado con la actividad de la fosfolipasa $\mathrm{D}$, la cual disminuye hasta $30-35$ días después de la cosecha y luego se estabiliza en valores entre $3.0 \times$ $10^{-4}$ y $3.8 \times 10^{-4} \mathrm{mmol}$ de colina/(min. g de soja).

PALABRAS-CLAVE: Almacenamiento - Fosfátidos - Fosfolipasa $D$ - Glycine max. - Humedad - Soja.

\section{SUMMARY}

Phosphatides content in soybean oil in function of bean moisture content-at-harvest and storage-time.

The influence of soybean moisture content-at-harvest and storage time upon total and non-hydratable phosphatides content in oil and bean phospholipase D activity was evaluated. Tests were performed upon soybeans harvested with moisture contents between 14.4 and $33.3 \%$ weight wet basis (wb). They were air dried at $25^{\circ} \mathrm{C}$ until achieving safe storage moisture contents between 12.8 and $13.5 \% \mathrm{wb}$ and were stored at the same temperature for 245 days. Periodically they were analyzed for total and non-hydratable phosphatides content and phospholipase $D$ activity. Total phosphatides initial content was high in soybeans with higher initial moisture levels and decreased slightly with time. Total phosphatides content remained constant at their initial levels in soybeans with lower initial moisture content. Non-hydratable phosphatides content was related to the phospholipase D activity, which decreased 30-35 days after harvest, and then stabilized, with values between $3.0 \times 10^{-4}$ and $3.8 \times 10^{-4}$ choline $\mathrm{mmol} /(\mathrm{min} \cdot$ soybean $\mathrm{g}$ ).

KEY-WORDS: Glycine max.- Moisture - Phosphatides - Phospholipase $D$ - Soybean - Storage.

\section{INTRODUCTION}

In refined soybean oil production it is necessary to eliminate the phosphorus contained as phosphatides. The simplest process is the aqueous degumming. The presence of non-hydratable phosphatides (NHP) makes necessary more complex degumming processes, which rises both, operation costs and oil lost. (Zhang et al., 1994). The phospholipase D activity turns hydratable phosphatides into non-hydratable ones (Haraldsson, 1983). The enzyme gets free during soybean cracking and flaking operations (List et al., 1992). Phospholipase D activity increases with temperature, and its highest activity is at $85{ }^{\circ} \mathrm{C}$ (Kock, 1983). Temperatures closer to $110^{\circ} \mathrm{C}$ produce its inhibition. Nakayama et al. (1981) studied the soybean phosphatides decomposition along with time and grain initial moisture content at $35{ }^{\circ} \mathrm{C}$ and $13.00 \%$ wb. They found a $72 \%$ hydratable phosphatides decomposition, but they did not mention moisture content at harvest and if grains were naturally or artificially dried. Very low moisture contents of soybeans at harvest increase the lost of grain as a consequence of plant falling down and pod opening. Producers collect soybeans at higher moisture contents and dry it up to lower moisture levels.

The aim of this work is to evaluate the incidence of soybean moisture content-at-harvest and storage time on the phospholipase $D$ activity on soybeans, the total phosphatides content in the crude oil, and the non-hydratable phosphatides content in the degummed crude oil.

\section{MATERIALS AND METHODS}

\subsection{Materials}

Coker 6847, seed grade soybean, from the same cultivar, collected during the 1997 harvest. Samples were collected manually when moisture contents were 33.3, 25.4, 21.8 and $16.8 \% \mathrm{wb}$, and mechanically at ripening time, with moisture contents 
of $14.4 \%$ wb. Soybean lecithin was from ICN Pharmaceuticals Inc. (Costa Mesa, CA), ammonium tetrathiocyanodiammonochromate (ammonium reineckate) was from Sigma Chemical Company (St. Louis, MO), other chemicals used were purchased from Merck (Darmstadt, Germany). All were ACS reagent grade.

\subsection{Storage}

Moist soybeans samples were air dried at $25^{\circ} \mathrm{C}$ immediately after harvested until moisture content reached between 12.8 and $13.5 \%$ wb. Samples were stored in hermetic cap containers at $25^{\circ} \mathrm{C}$. Phospholipase D activity in soybeans, and total and non-hydratable phosphatides content in extracted oil were determined on stored samples. Determinations every 7 days for the first 56 days after harvesting were performed, then every 14 days until day 140 , and finally every 21 days until completing 245 days. Moisture content determination was carried out according to AOCS Ac 241.

\subsection{Total and non-hydratable phosphatides determination.}

To obtain crude oil (CO) and degummed crude oil (DCO) for analytical purposes, soybean samples, stored for a certain number of days, were submitted to the same stages as the commercial solvent oil extraction processing. They were conditioned by air drying until moisture content ranged between 9.8 and $11.5 \%$ wb. Then they were cracked into 6-8 pieces in a dish mill, heated at $60^{\circ} \mathrm{C}$ for 1 hour in a hermetic container with periodic shaking, and flaked in a pilot scale equipment. Flake mean thickness was $0.22 \mathrm{~mm}$. Oil extraction was performed on $250 \mathrm{~g}$ of flakes with $n$-hexane in a Butt extractor. The miscela, containing the solvent and the extracted oil, was desolventized in a rotary evaporator under nitrogen current, applying a $3.3 \mathrm{kPa}$ vacuum in the final stage. For the degumming stage, $2 \%$ distilled water was added to an aliquot of the obtained crude oil and shaked for 15 minutes at constant temperature (60 ${ }^{\circ} \mathrm{C}$ ) in a bath. The gums were separated by centrifugation at 2,000 $g$ RCF for $15 \mathrm{~min}$. Phosphorus determination in CO and DCO was carried out following the method proposed by Tosi et al. (1998). Total and non-hydratable phosphatides contents in crude and degummed oil were expressed as total and non-hydratable phosphorus in $\mu \mathrm{g} / \mathrm{g}$ oil respectively.

\subsection{Phospholipase $D$ activity determination}

Instead of extracting the enzyme from the soybean matrix, a method that put lecithin (as substrate) in contact with phospholipase D without extracting it from soybeans was employed. The choline formed by the enzyme activity was measured by a known method. Briefly, the method steps are: a) whole soybean grains were milled in a IKA A 10 refrigerated mill (Janke \& Kunkel GmbH \& Co., Staufen, Germany), until they passed through a 40 ASTM mesh. b) $0.150 \mathrm{~g}$ of milled soybean was mixed with $10 \mathrm{ml}$ of a $5 \%$ soybean lecithin in ethyl ether solution as substrate, $0.1 \mathrm{ml}$ of $0.1 \mathrm{M}$ calcium chloride solution and $10 \mathrm{ml}$ acetate buffer $\mathrm{pH} 5.6$ and incubated in a shaking bath during 3 hours at $0{ }^{\circ} \mathrm{C}$. c) reaction was stopped by adding $1 \mathrm{ml}$ trichloroacetic acid. d) ethyl ether was eliminated by vacuum e) the remaining solid was separated by centrifugation at 2,000 $\mathrm{g}$ RCF for $15 \mathrm{~min}$. f) choline was quantified in the supernatant, by the Möllering and Bergmeyer method (Bergmeyer and Gawehn, 1974). Phospholipase D activity was expressed as $\mathrm{mmol}$ of choline formed by the enzyme for minute and soybean gram, (mmol choline/min - soybean $\mathrm{g}$ ). Determinations were carried out by triplicate.

\section{RESULTS AND DISCUSSION}

Figures 1 and 2 show total and non-hydratable phosphorus contents in crude oil and degummed crude oil respectively, and Figure 3 shows soybean phospholipase D activity, as function of soybean moisture contents at harvest and storage time.

Crude oil total phosphatides initial contents were high in soybean with higher moisture content at harvest, and those values remained constant even if grains were dried before stored. The total phosphatides content in soybeans with $33.3 \%$ wb moisture content at harvest reached $1000 \mu \mathrm{g}$ phosphorus/g oil being $80 \%$ higher than in soybeans with low moisture content. After a slight decrease, the total phosphatide content remained at high values, when compared to grains collected with low moisture content. The total phosphatides content maximum reduction corresponded to 33.3 moisture

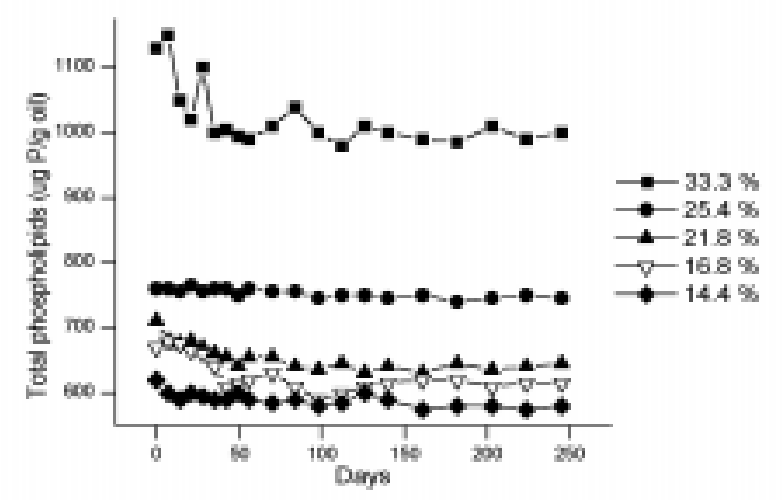

Figure 1

Total phosphatides content in crude oil vs. soybean storage time for different initial moisture contents. 


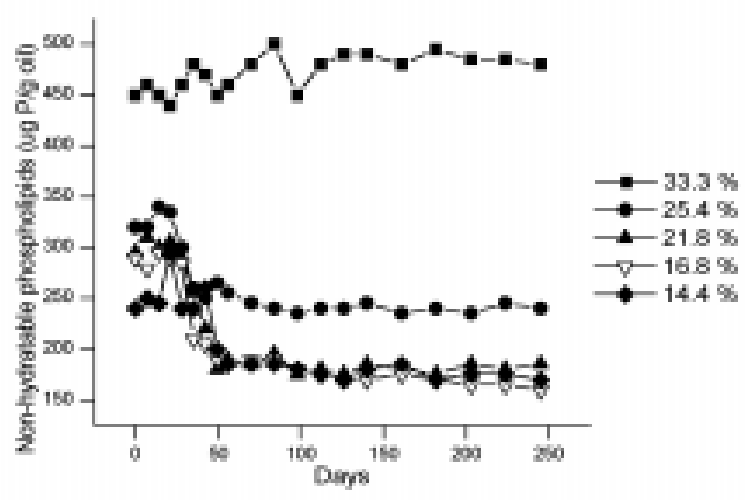

Figure 2

Non-hydratable phosphatides content in degummed crude oil vs. soybean storage time for different initial moisture contents.

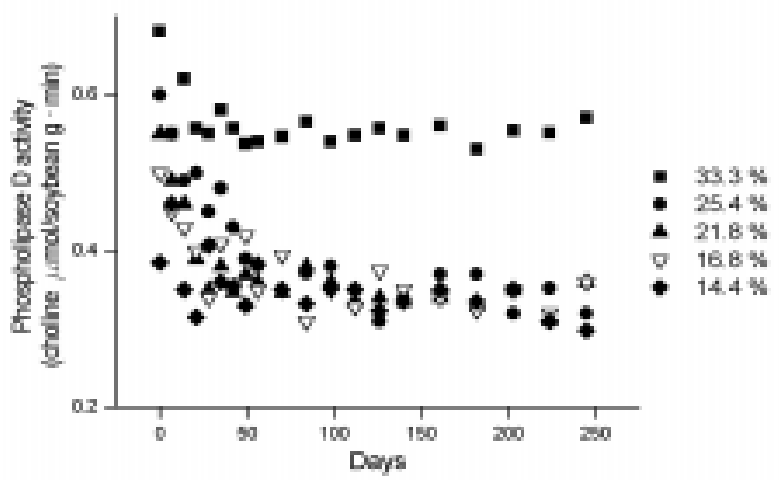

Figure 3

Soybean phospholipase D activity vs. soybean storage time for different initial moisture contents.

content samples with $11.5 \%$, being $7.5 \%$ the mean reduction considering all moisture contents evaluated.

Degummed crude oil non-hydratable phosphatide content was a function of both the initial moisture content and the phospholipase D activity of the tested soybeans, and decreased when the enzymatic activity was low (List et al, 1992). Stabilization values seem to depend on soybean moisture content at harvest. For initial moisture contents comprised between 14.4 and $25.4 \%$, the non-hydratable phosphatides content was close to $300 \mu \mathrm{g}$ phosphorus $/ \mathrm{g}$ oil in the first 30-42 days. During the next fifty days it diminished slowly and stabilized at values between 160-240 $\mu \mathrm{g}$ phosphorus/g oil at test end. For the highest initial moisture content of $33.3 \%$, the non-hydratable phosphatides content increased from 450 initial value to $485 \mu \mathrm{g}$ phosphorus/g oil at the end of the study. This increase corresponds to the high phospholipase $\mathrm{D}$ activity at high moisture contents.
The non-hydratable phosphatides content maximum reduction was $45 \%$ for the $16.8 \%$ initial moisture content sample. The mean reduction was $35.3 \%$, without considering the $33.3 \%$ sample, which increases until $11 \%$ its non-hydratable phosphatides content. Those results, seemed to differ from the ones of Nakayama et al. (1981) who observed a higher conversion, but it is difficult to arrive to a general conclusion because their experimental conditions are not thoroughly known.

Soybean phospholipase $\mathrm{D}$ activity decreased along with storage time, and stabilized at values ranging between $3.0 \times 10^{-4}$ and $3.8 \times 10^{-4} \mathrm{choline} \mathrm{mmol} /(\mathrm{min}$. soybean $\mathrm{g}$ ), after 30-35 days from harvest, for initial moisture contents comprised between 14.4 and 25.4 $\%$. For $33.3 \%$ initial moisture content soybeans, the phospholipase $\mathrm{D}$ activity reduced slightly during the study.

\section{CONCLUSION}

Non hydratable phosphatides content remaining in the degummed crude oil after the aqueous degumming process is dependent on the soybeans moisture level at harvest, and its phospholipase $D$ activity, and cannot be modified by a low temperature post-harvest drying. From the oil milling industries standpoint, soybeans must be harvested after ripening, with a moisture level compatible with harvesting techniques.

\section{REFERENCES}

AOAC, Official Method and Recommended Practices the AOCS. (1997). Association of Official Analytical Chemists, Washington, DC.

Bergmeyer, H.U., and Gawehn, K. (1974) Enzimes as Biochemical Reagents, Methods of Enzymatic Analysis, $2^{\text {nd }}$ edn., Academic Press, New York, Vol. I, p. 504.

Haraldsson, G. (1983). Degumming, Dewaxing and Refining. J. Am. Oil Chem. Soc., 60, 251-256.

Kock, M. (1983). Oilseed Pretreatment in Connection with Physical Refining. Ibid., 60, 198-202.

List, G., Mounts, T. and Lanser, C. (1992). Factors Promoting the Formation of Nonhydratable Soybean Phosphatides. Ibid., 69, 443-446.

Nakayama, K., Saio, K. and Kito, M. (1981). Decomposition of Phospholipids in Soybean During Storage. Cereal Chemistry, 58, 260-264.

Tosi, E., Cazzoli, A. and Tapiz, L. (1998). Phosphorus in oil. Production of Molybdenum Blue Derivative at Ambient Temperature Using Non-Carcinogenic Reagents. J. Am. Oil Chem. Soc., 75, 41-44.

Zhang, S., Koseoglu, S. and Rhee, K. (1994). Effects of Expander Process on the Phospholipids in Soybean Oil. J. Am. Oil Chem. Soc., 71, 1145-1148. 